\title{
CONSTITUTIONAL IMPLICATIONS OF EU MEMBERSHIP: A VIEW FROM THE COMMISSION
}

\begin{abstract}
Frank Hoffmeister*
Summary: This article reviews the constitutional implications of EU membership from a European Commission perspective.

It first recalls the ratification procedures in both the old and the new Member States. The author identifies five different groups in this regard. A few Member States apply constitutional provisions on the ratification of international treaties. Others have recourse to a clause which refers to limitations of national sovereignty. The vast majority ratify the founding treaties or the Accession Treaty on the basis of a transfer/delegation of powers clause, or use a clause allowing the common exercise of powers. Finally, some Member States apply special constitutional procedures to bring about EU membership. Despite these theoretical differences, their impact on the actual procedure is less significant. Basically, European treaties are either ratified as other international treaties, or the required majorities in Parliament for ratification rises compared to the parliamentary majorities needed for ordinary international treaties. Sometimes, the need to hold an additional referendum arises, or special constitutional procedures need to be fulfilled.

Second, the article compares the domestic rank of European law. It shows that virtually all 27 Member States accept the supremacy of Community law over national statutes. This can be deduced from the text of the integration clauses or their function. The situation is different when it comes to the relationship between Community law and national constitutional law. Here, supremacy of Community law is either rejected, accepted or put under a reserve as regards basic constitutional principles.

Third, the paper lists specific constitutional clauses relating to EU matters. It shows that a number of Member States changed their constitutions to allow for voting rights for EU citizens in local elections. Furthermore, constitutional prohibitions to extradite nationals were lifted to be able to comply with the European Arrest Warrant. Moreover, bans on foreigners acquiring real property were abolished, as they were not compatible with the free movement of capital. Community
\end{abstract}

\footnotetext{
${ }^{*}$ Dr. iur., Member of the European Commission Legal Service. Professor of Law (part-time) at the Vrije Universiteit Brussels. The views expressed are purely personal. I wish to thank J Czuczai, I Pernice, P van Nuffel, and B de Witte for useful comments on earlier drafts which significantly improved this piece. The responsibility for any mistakes certainly rests with the author.
} 
rules on economic and monetary union triggered several amendments related to the independence and function of national banks. Finally, a few candidate countries modified their constitutions to align themselves with a rising corpus of 'constitutional acquis' relating to the independence of the judiciary.

The article concludes that the European Commission does not prescribe a specific method on how a candidate should address these issues. Rather, during the negotiations, it points to certain shortcomings as they arise in the negotiation chapters. There is an obligation of result to provide for the supremacy of Community law by accession. The choice on how and when to opt for a constitutional model which is best reconcilable with the candidate's own national tradition certainly remains in the hands of the democratically elected representatives of the candidate country itself.

\section{Introduction}

When a candidate country joins the European Union, European law ${ }^{1}$ becomes applicable in the new Member State under the conditions laid down in the Treaty of Accession. ${ }^{2}$ Whereas there is a duty of loyalty for Member States to carry out obligations arising under the second or third pillar of the European Union, ${ }^{3}$ the respective obligations under the first pillar have long been recognised as being of particular significance. In its opinions on previous enlargements, the European Commission stressed, among other things, that 'Community law takes precedence over any national provisions which may conflict with it' (emphasis added). ${ }^{4}$ This dictum reflects the long-standing jurisprudence of the European Court

\footnotetext{
1 Under Article 1 (3) of the Treaty Establishing the European Union, the European Union is founded on the European Communities, supplemented by the policies and forms of cooperation established under the EU Treaty. In this contribution, the term 'European law' will be used to describe the law arising from all three pillars. Law arising under the $2^{\text {nd }}$ pillar (Common Foreign and Security Policy) or under the $3^{\text {rd }}$ pillar (Police and Judicial Cooperation in Penal Matters) will be referred to as 'EU law'. Finally, the law arising under the $1^{\text {st }}$ pillar is labelled 'Community law'.

2 The Treaty of Accession usually contains a short main body and the Act of Accession with numerous Protocols and Annexes as its integral part.

3 Article 11 (2) EU; ECJ Case C-105/03, Maria Pupino, [2005] ECR I-5285, Rec 42 of judgment.

4 The Commission's opinion of 19 February 2003 on the application for accession to the European Union by the Czech Republic, the Republic of Estonia, the Republic of Cyprus, the Republic of Latvia, the Republic of Lithuania, the Republic of Hungary, the Republic of Malta, the Republic of Poland, the Republic of Slovenia and the Slovak Republic (OJ 2003, L 236, pp 3, 4, § 10); The Commission's opinion of 22 February 2005 on the application for accession to the European Union by Bulgaria and Romania (OJ 2005, L 157, pp 3, 4, para 8).
} 
of Justice, according to which Community law enjoys supremacy over national law, including constitutional law. ${ }^{5}$ Accordingly, in the case of a conflict, national administrations and courts are obliged to apply the relevant rule of Community law and not to apply the conflicting rule of national law ${ }^{6}$ or contracts concluded between social partners (Anwendungsvorrang). ${ }^{7}$

While the supremacy of Community law does not mean that contradicting national law becomes invalid (Geltungsvorrang), this principle presents nevertheless a major challenge to national legal systems. From a domestic point of view, the constitution is the highest legal norm and other sources are subordinated to it. Hence, ways must be found to reconcile obligations arising from Community law and the legal heritage of a country. As European law is integrated into the domestic law of a candidate country in ratifying the Treaty of Accession, two aspects thereof should be distinguished: the ratification procedures and the following rank of Community law vis-à-vis national law. Next to such horizontal solutions, the constitutional legislator sometimes tackles specific policy fields where conflicts are likely to occur. This paper will review how the present Member States have accommodated the supremacy of Community law over its domestic law in these three areas. In doing so, the practice of both the old and the new Member States is taken into account. Finally, a tentative conclusion from the Commission perspective is presented.

Certainly, this is somewhat of a hazardous exercise, since much of the information gathered in this contribution summarises the experience in the Member States at second hand. Hence, this summary inevitably derives from national reports ${ }^{8}$ and first comparative works ${ }^{9}$ and may seem,

5 ECJ Case 11/70, Internationale Handelsgesellschaft [1970] ECR 1125, 1135 para 3; ECJ Case 149/79 Commission vs. Belgium [1980] ECR 3881, 3903 para 19; ECJ Joined Cases 97-99/87 Dow Chemical Ibérica and others vs. Commission [1989] ECR 3165 paras 37-38; ECJ Case 473/93, Commission v. Luxemburg [1996] ECR I-3207, 3258 paras 37-38.

6 ECJ Case 106/77 Simmenthal [1977] ECR 1978, 629 paras 21-24.

7 ECJ Case C-184/89 Nimz [1991] I-321 para 20.

8 For national reports of the topic, see, inter alia, A Kellermann, J De Zwaan, J Czuczai (eds), EU Enlargement: The Constitutional Impact at EU and National Level (Asser Press, The Hague 2001); W Sadurski, J Ziller and K Zurek (eds), Après Enlargement, Legal and Political Responses in Central and Eastern Europe (Florence EUI-RSCAS, 2006); A Kellermann, J Czuczai and others (eds), The Impact of EU Accession on the Legal Orders of the New Member States and (Pre-)Candidate Countries (Asser Press, The Hague 2006).

9 J Dutheil de la Rochère, I Pernice, 'General Report' in International Federation of European Law, FIDE XX Congress London 2002, (British Institute of International and Comparative Law 2003) 1-64; A Albi, EU Enlargement and the Constitutions of Central and Eastern Europe (Cambridge University Press 2005); A Albi, "'Europe" - Articles in the Constitutions of Central and Eastern Countries' 42 CMLRev (2005) 399-423; A Albi 'Supremacy of EC Law in the New Member States - Bringing Parliaments into the Equation of "Co-operative Constitutionalism"' 3 European Constitutional Law Review (2007) 25-67; J Czuczai, 'Constitutional Preparation for EU Accession in the New Central and Eastern European Member 
given the need to respect space, somewhat superficial. Nevertheless, it is hoped that the disadvantages of this approach can be partly offset by providing an overall survey which includes the present 27 Member States and their relevant case law, as far as possible, up to 2006.

\section{Ratification procedures}

\section{The founding Member States}

When the founding States pooled some of their sovereign powers by creating the European Coal and Steel Community (1951), the European Atomic Energy Community and the European Economic Community (1957), they relied on different constitutional provisions. ${ }^{10}$ The post-war constitutional law makers of Germany and Italy, facing the horrors of the fascist past, had put special emphasis on international cooperation. Hence, the Italian Constitution of 1947 contained a specific clause on the limitations of sovereignty, ${ }^{11}$ and the German Basic Law of $1949^{12}$ allowed for the transfer of powers to international organisations backing the ratification of the EC founding treaties. The Netherlands introduced a constitutional amendment in 1953 to face ECSC membership. ${ }^{13}$ Under the new Article 67 (now Article 92), legislative, administrative and judicial powers could be transferred to international organisations. Moreover, international treaties capable of binding citizens would prevail over earlier or later provisions of national law. Furthermore, unconstitutional treaties could nevertheless be ratified provided that a two-thirds majority in both houses of Parliament support the ratification. ${ }^{14}$ In Luxemburg, a constitutional amendment of $1956^{15}$ foresaw that the transfer of legisla-

States: Is the Rule of Law Better Than the Rule of Politics?' in J de Zwaan, JH Jans and others (eds) The EU - An Ongoing Process of Integration: Liber Amicorum Afred E. Kellermann (Asser Press 2004) 269-283.

10 For an excellent overview, see B de Witte, 'Constitutional Aspects of European Union Membership in the Original Six Member States: Model Solutions for the Applicant Countries?' in A Kellermann, J De Zwaan, J Czuczai (eds), EU Enlargement (n 8) 65, 67-73.

11 Article 11 of the Italian Constitution stipulates: 'Italy (...) agrees to the limitations of sovereignty necessary for an order that ensures peace and justice among Nations.'

12 Article 24 (1) of the Basic Law provides: 'The Federation may transfer powers to international bodies by law.' As of the constitutional amendments of 1992, this article is no longer applicable for the transfer of powers to the EU (see below).

13 J Peters, 'The Dutch Constitution and Dutch Constitutional Values' in Kellermann, de Zwaan, Czuczai (eds), EU Enlargement (n 8) 57, 58.

14 For more details, see HF Jonkheer, van Panhuys, 'The Netherlands Constitution and International Law' 47 AJIL (1953) 537-558.

15 Article $49 \mathrm{bis}$ of the Luxemburg constitution, as revised by the amendment of 25 October 1956, reads: 'L'exercice d'attributions réservées par la constitution aux pouvoirs législatif, exécutif et judiciaire peut être temporairement dévolu par traité à des institutions de droit international.' 
tive, executive or judicial powers to international bodies could be effected by a two-thirds majority in Parliament. ${ }^{16}$ In France, limitations to sovereignty were already mentioned in recital 15 of the Preamble to the 1946 Constitution, and international treaties were attributed supremacy over French domestic law under Article 55 of the 1958 Constitution. ${ }^{17}$ Belgium proceeded to a constitutional amendment in 1970 by introducing Article 25 bis (today Article $34^{18}$ ) allowing the attribution of the exercise of powers to international bodies by law or by treaty.

While the respective ratification laws on the founding treaties only required a simple majority in Parliament (with the exception of Luxembourg), the procedural requirements became more stringent when the old Member States faced the Maastricht Treaty. Germany adopted a whole new Article 23 in 1992 specifically dedicated to the transfer of powers to the European Union. ${ }^{19}$ European law touching on German constitutional law could from thereon only be accepted by a two-thirds majority in both German chambers, ie the quorum that would also be needed for constitutional amendments. Also France reached the limits of passing simple ratification laws with regard to the Maastricht Treaty 1991. According to Article 54 of the French Constitution, ${ }^{20}$ the Constitutional Council delivered an opinion pointing to the need to change the French Constitu-

${ }_{16}$ Article 37 (2) in conjunction with Article 114 fifth sentence of the Luxemburg Constitution.

17 The 1958 Constitution incorporates also by reference the Preamble of the 1946 Constitution, including its recital 15.

18 Article 34 of the Belgian Constitution reads: 'The exercise of delimited powers can be attributed by treaty or by law to the institutions of public law'.

19 Article 23 (1) of the Basic Law reads: '(1) For the realisation of a unified Europe, the Federal Republic of Germany participates in the development of the European Union which respects democracy, rule of law, social and federal principles and the principle of subsidiarity and which ensures a level of human rights protection that is comparable to the one afforded by the Basic Law. The Federation may transfer to this end powers by law with the assent of the Bundesrat. For the establishment of the European Union as well as modifications of its legal bases through which the Basic Law is changed or amended in its contents, Article 79 (2) and (3) are applicable.'

Hence, a transfer of power to the EU needs a simple majority in the Bundestag (House of Representatives ) plus assent in the Bundesrat (Federal Chamber) - Article 23 (1) 2 GG. If the transfer of powers entails a constitutional modification in Germany, the ratification law must be adopted by a two-thirds majority in both chambers - Article 23 (1) 3 GG in conjunction with Article 79 GG.

20 Article 54 of the French Constitution says:

'Si le Conseil Constitutionnel, saisi par le Président de la République, par le Premier Ministre, par le Président de l'une ou l'autre assemblée ou par soixante députés ou soixante sénateurs, a déclaré qu'un engagement international comporte une clause contraire à la constitution, l'autorisation de ratifier ou d'approuver l'engagement international en cause ne peut intervenir qu'après révision de la constitution.' 
tion on some points ${ }^{21}$ prior to the ratification of the Maastricht treaty. ${ }^{22}$ Indeed, a new title dedicated to EU matters was inserted after the tough procedure of gaining a three-fifths majority in 'congress', ie the common meeting of the Senate and House of Deputies under Article 89 (3) of the French Constitution. One of the amendments led to a new 'Europe Article' in Article 88 (1) of the constitution. ${ }^{23}$

\section{The United Kingdom, Ireland and Denmark}

In 1972, the United Kingdom House of Commons adopted the European Communities Act for the ratification of its Accession Treaty by simple majority. In Denmark, Paragraph 20 (2) of the Constitution allows for the delegation of powers to international authorities by statute adopted by a five-sixths parliamentary majority or a simple majority in a popular vote if the former is not reached. ${ }^{24}$ Following an agreement of the Danish political parties to submit the treaty to the people without prior vote in Parliament, the referendum of 2 October 1972 found $57 \%$ of Danes voting in favour. Ireland proceeded to a constitutional amendment by referendum. The people voted for a provision according to which Ireland could accede to the Communities. ${ }^{25}$ Following the Crotty decision of the Supreme Court relating to the Single European Act, ${ }^{26}$ this procedure has to be repeated in Ireland each time the Treaties touch upon Irish constitutional law. It follows therefrom that the Irish Constitution contains a chronology of the constitutional developments in the Community. ${ }^{27}$

\footnotetext{
${ }^{21}$ For more details, see below Section IV.

22 Conseil Constitutionel, Décision no 92-308, = RFDC 1992, 334. See B Genevois, 'Le Traité sur l'Union Européenne et la Constitution', 8 RFDA (1992) 373ff; Ch. Walter, 'Die drei Entscheidungen des französischen Verfassungsrats zum Vertrag von Maastricht über die Europäische Union', 19 EuGRZ (1993) 183ff; P Oliver, 'The French Constitution and the Treaty of Maastricht', 43 ICLQ (1994) 1.

23 Article 88-1 of the French Constitution reads: 'La République participe aux Communautés européennes et à l'Union européenne, constituées d'Etats qui ont choisi librement, en vertu des traités qui les ont instituées, d'exercer en commun certaines de leurs compétences.'

$24 \S 20$ of the Danish Constitution provides (translation by the author): ‘(1) Powers which belong to the authorities of the King under this constitution may be transferred by law to a certain degree to international bodies which are established by international agreement to promote the international rule of law and cooperation. (2) Draft laws must be adopted by five-sixths of the Members of the Folketing. If such a majority is not achieved, but only a simple majority, the Government may submit the draft law to the people for a referendum according to the provisions in $\S 42$.'

25 Article 29 (4) (3) of the Irish Constitution reads: 'The State may become a member of the European Coal and Steel Community (...), the European Economic Community (...) and the European Atomic Energy Community.'

26 Crotty $v$. An Taoiseach [1987] IR 713.

27 Article 29 (4)-(7) contains references to all the subsequent Treaty changes in the Community (Single European Act, Treaty of Maastricht, Treaty of Amsterdam, Treaty of Nice).
} 


\section{Greece, Portugal and Spain}

In Greece, the Constitution allows for the transfer of powers to international bodies with a majority of three-fifths in Parliament, whereas limitations of sovereignty can already be passed with an absolute majority. ${ }^{28}$ Legal scholars did not agree whether ratification of the EC treaty would fall under the first or second category, or under both. ${ }^{29}$ However, this dispute did not play a role in practice, since the large majority in the Greek Parliament voting in favour of accession on 28 June 1979 easily met the three-fifths threshold. According to Articles 93 of the Spanish constitution, the exercise of State functions can be transferred by way of an organic law. ${ }^{30}$ Accordingly, the Spanish ratification law of $2 \mathrm{Au}-$ gust 1985 had to gain at least an absolute majority in both chambers of Parliament. In contrast, Article 161 (i) of the Portuguese Constitution of 1976 required only a simple majority in Parliament for the Portuguese ratification law. ${ }^{31}$ Portugal changed this approach when it inserted a general clause into its Constitution allowing for the common exercise of powers in the $\mathrm{EU}^{32}$ prior to the ratification of the Maastricht Treaty. ${ }^{33}$

For more details, see G Hogan, 'Ireland and the European Union: Constitutional Law and Practice' in Kellermann, De Zwaan and Czuczai (eds), EU Enlargement (n 8) 89, 91-93.

28 Article 28 of the Greek Constitution stipulates: ‘(2) Authorities provided by the constitution may by treaty or agreement be vested in agencies of international organisations, when this serves an important national interest and promotes cooperation with other States. A majority of three-fifths of the total number of Members of Parliament shall be necessary to vote the law sanctioning the treaty or agreement. (3) Greece shall freely proceed by law passed by an absolute majority of the total number of Members of Parliament to limit the exercise of national sovereignty, insofar as this is dictated by an important national interest, does not infringe upon the rights of man and foundations of democratic government and is effected on the basis of the principles of equality and under the conditions of reciprocity.'

29 K Chryssogonos, 'The European Union and the Greek Constitutional Order' in Kellermann, De Zwaan and Czuczai (eds.), EU Enlargement (n 8) 141, 142.

30 Article 93 of the Spanish Constitution reads: 'Mediante la ley orgánica se podrá la celebración de tratados por los que se atribuya a una organización o institución el ejercicio de competencias derivadas de la Constitución. Corresponde a las Cortes General o al Gobierno, según los casos, la garantia del cumplimiento de estos tratados y de las resoluciones emanadas de los organismos internacionales o supranacionales titulares de la cesión.'

31 Article 161 i) of the Portuguese Constitution provides: 'The Assembly of the Republic has the following powers: i) To approve international conventions, specifically treaties for the membership of Portugal in international organisations, treaties of friendship, of peace, for defence or to rectify boundaries, or concerning military matters (...).'

32 Article 7 VI of the Portuguese Constitution, as amended in 1992, stipulates: 'Provided that there is reciprocity, Portugal may enter into agreements for the joint exercise of the powers necessary to establish the European Union, in ways that have due regard for the principle of subsidiarity and the objective of economic and social cohesion.'

33 R. M. Moura Ramos, 'The adaptation of the Portuguese Constitutional Order to Community Law' in Kellermann, De Zwaan and Czuczai (eds), EU Enlargement (n 8) 131, 133. 


\section{Austria, Finland and Sweden}

All three acceding countries of 1995 put the decision on EU accession to popular vote, although this was not constitutionally obligatory. ${ }^{34}$ Austria decided to proceed to a total revision of the Constitution because EU accession was regarded to touch upon a number of fundamental constitutional principles, such as democracy, the rule of law and the separation of powers. ${ }^{35}$ This revision required the participation of the people and a two-thirds majority in both chambers of Parliament under Article 44 (3) of the Constitution. ${ }^{36}$ Only after the positive vote of the Austrian people did the Parliament enact the Constitutional Act on Austria's Accession and the Austrian President signed the Accession Treaty. A consultative referendum prior to the adoption of a parliamentary ratification bill occurred in Sweden. That Act was then passed on the basis of a constitutional amendment allowing the transfer of powers to the European Communities and calling for a three-fourths majority in the Swedish Parliament or for the procedure applying to basic laws. ${ }^{37}$ Finland held a consultative referendum before acceding to the European Union. Following its dualist tradition, accession entailed two steps: ${ }^{38}$ the House could vote with a simple majority on the international ratification of the Accession Treaty; however, as the substance of the Treaty was considered to be unconstitutional, the Finnish EU Accession Act required a two-thirds majority

34 F. Granell, 'Les conditions d'adhésion de l'Autriche, de la Finlande, de la Norvège et de la Suède à l'Union Européenne', Revue du Marché Commun (1994) 583-591.

35 S. Griller, 'Introduction to the Problems in the Austrian, the Finnish and Swedish Constitutional Order' in Kellermann, De Zwaan and Czuczai (eds), EU Enlargement (n 8) 147, 148.

36 Article 44 (3) of the Austrian Constitution reads: 'Jede Gesamtänderung der Bundesverfassung, eine Teiländerung aber nur, wenn dies von einem Drittel der Mitglieder des Nationalrates oder des Bundesrates verlangt wird, ist nach Beendigung des Verfahrens gemä $\beta$ Artikel 42, jedoch vor der Beurkundung durch den Bundespräsidenten, einer Abstimmung des gesamten Bundesvolkes zu unterziehen.' For more details on the Austrian approach, see T Oehlinger, Verfassungsfragen einer Mitgliedschaft zur Europaeischen Union (1999) with annotation by F Hoffmeister, Deutsches Verwaltungsblatt (2000) 1296.

37 Chapter 10, Article 5 of the Swedish Constitution reads: 'The Riksdag may entrust the right of decision-making to the European communities so long as these provide protection for rights and freedoms corresponding to the protection provided under this Instrument of Government and the European Convention for the Protection of Human Rights and Fundamental Freedoms. The Riksdag authorises such delegation in a decision which has the support of at least three-fourths of those present and voting. The Riksdag may also take such a decision in the manner prescribed for the adoption of a fundamental law.'

In practice, the Swedish Parliament decided to use the second option (procedure for the adoption of a fundamental law). Hence, the bill on the Act of Accession was voted by Parliament; then Parliament was dissolved, and the newly elected Parliament confirmed the bill. With the consensus of two differently composed Parliaments, the bill entered into force.

38 A Rosas, 'Finland's accession to the European Union: Constitutional Aspects' 1 European Public Law (1995) 166-170. 
under the standing orders of Parliament. The new Finnish Constitution of 2000 subsequently harmonised the external and the internal procedure. Under a new provision, international treaties with constitutional impact henceforth need parliamentary ratification with a two-thirds majority. ${ }^{39}$

\section{The twelve new Member States}

\section{a) Malta and Cyprus}

In Malta, section 6 of the Constitution provides for its supremacy over any other law, which to the extent of the inconsistency shall be void. In 1990, a government report advised amending this section so that the Constitution would also become subject to Community law. However, such an amendment would require a two-thirds majority in Parliament under Article 66 (2) (b) of the Constitution. As such a majority was unlikely to occur given the firm opposition of the main opposition party to EU accession, the report went on to argue that short of an amendment to section 6, a declaration that Community law prevails over Maltese law should be inserted in an ordinary Act of Parliament. ${ }^{40}$ As the bipolar political situation in Malta continued to exist during the course of accession, the accommodation of EU membership actually followed this line of thinking in 2003. The government submitted to the people the question whether Malta should become a member of the European Union. In the referendum of 8 March 2003, over 90\% of Maltese voters participated and a majority of $53.65 \%$ voted in favour. From a constitutional point of view, this vote was only consultative. Two months after signing the Accession Treaty, on 16 July 2003, the Maltese Parliament adopted the European Union Act (with 34 votes in favour and 25 against). ${ }^{41}$ That Act could not modify Section 6 of the Constitution (protected by a two-thirds threshold under Section 66), but revised Section 65 of the Constitution ${ }^{42}$ which

\footnotetext{
39 Article 94 (2) of the Finnish Constitution of 11 June 1999 (entered into force 2000) reads: 'A decision concerning the acceptance of an international obligation or the denouncement of it is made by a majority of the votes cast. However, if the proposal concerns the constitution or an alteration of the national borders, the decision shall be made by at least two-thirds of the votes cast.'

40 Report from the EC Directorate to the Prime Minister and the Minister of Foreign Affairs, Department of Information, March 1990, quoted by P. G. Xuereb, 'Constitutional Questions Raised by the Proposed Accession of Malta to the European Union' in Kellermann, De Zwaan and Czuczai, EU Enlargement (n 8) 229, 230-231.

41 Act V of 2003 - European Union Act (Chapter 460) of 16 July 2003. Section 6 says: 'For the purposes of the ratification of Treaties Act the Government of Malta is hereby authorised to ratify the (Accession) Treaty.'

42 Section 7 of the European Union Act provides: 'For subarticle (1) of article 65 of the constitution, there shall be substituted the following: (1) Subject to the provisions of this constitution, Parliament may make laws of the peace, order and good government of Malta in conformity with full respect for human rights, generally accepted principles of international
} 
concerned the law-making powers of the House and was not protected by Article $66 .^{43}$

In the Republic of Cyprus, the rigid Constitution of 1960 is the supreme law of the land, as expressly stated in Article 179. Furthermore, several Articles on the powers of State institutions were identified as being potentially incompatible with EU membership. ${ }^{44}$ Following this analysis, the Attorney-General Markides serving under President Clerides, supported by some doctrine in Cyprus, took the view that a modification of the Constitution prior to EU accession was desirable in May 2002. ${ }^{45}$ Ideas about a consultative referendum that would conform with the sovereign right of the people to choose their own form of government and to determine relations with other nations were also floated. ${ }^{46}$ However, against the background of ongoing talks between the Greek Cypriot and Turkish Cypriot leaders on a settlement of the political problem and UN mediation on the issue, the government under President Papadopoulos (in office since spring 2003) did not put a constitutional amendment to the Parliament following an opinion of the new Attorney-General to the effect that no amendment of the Constitution was needed prior to the ratification of the Treaty. ${ }^{47}$ Accordingly, the House merely approved an act of ratification to the Accession Treaty on 14 July 2003 under Article 169 of the Constitution and no EU accession referendum was held. A constitutional amendment with a majority of (presently only Greek Cypriot) Members of the House was, however, passed after Cyprus had already become an EU Member State in 2006. ${ }^{48}$

\section{b) Lithuania, Latvia, Estonia}

In the Baltic States, any constitutional amendment on articles on sovereignty and independence necessitates a referendum. This is why the process of amendment in these countries has been most difficult and

law and Malta's international and regional obligations, in particular those assumed by the treaty of accession to the European Union, signed in Athens on the $16^{\text {th }}$ of April 2003.'

43 For a discussion whether or not an amendment to Section 65 of the Maltese Government was necessary, see PG Xuereb, 'Constitutional Questions Raised by the Proposed Accession of Malta to the European Union' in Kellermann, De Zwaan and Czuczai (eds), EU Enlargement (n 8) 229, 233.

44 N Emiliou, 'The Constitutional Impact of Enlargement at EU and National Level: the Case of the Republic of Cyprus' in Kellermann, De Zwaan and Czuczai (eds), EU Enlargement (n 8) 243, 249-250.

45 F Hoffmeister, Legal Aspects of the Cyprus Problem - Annan Plan and EU Accession (Brill 2006) 205 with further references.

46 Emiliou (n 44) 251.

47 N Emiliou, 'Cyprus' in Kellermann, Czuczai and others (eds), Impact of EU Accession (n 8) 303, 307.

48 See below Section III 1. 
controversial. ${ }^{49}$ Indeed, no such amendment occurred in Lithuania prior to accession ${ }^{50}$ despite numerous recommendations to insert a transfer of power clause. ${ }^{51}$ Accordingly, Article 136 of the Lithuanian Constitution remained sedes materiae in the pre-accession period. It provides that Lithuania shall participate in international organisations provided that they do no contradict the interests and the independence of the State. The article is silent on any special procedures related to such participation. Rather, under Article 9 (1) of the constitution, the most significant issues concerning the life of the State and the people shall be decided by referendum. From 10 to 11 May 2003, the population was asked to mark its approval or disapproval of the statement: 'I am for Lithuania's membership of the European Union.' In a turnout of 63.3\%, a high percentage of $91.04 \%$ of voters voted in the affirmative. The law of ratification to the Accession Treaty was adopted in Parliament under Article 84 point 11 of the Constitution on 16 September 2003 with 84 out of 87 votes in favour. However, ex post factum, the Parliament adopted on 13 July 2004 a separate Constitutional Act pursuant to Article 148 of the Constitution in two separate votes. According to Article 1 of this Act, Lithuania shares with or entrusts to the European Union competencies of its State institutions in the spheres provided for in the founding treaties of the European Union. ${ }^{52}$

In Latvia, EU accession led to some changes to the Constitution on 8 May 2003. Whereas Articles 1 and 2 on independence and sovereignty remained unchanged, ${ }^{53}$ a new Article 68 allows for the delegation of a part of State powers to international institutions. Such delegation may be ratified by the Saeima (Parliament) by a two-thirds majority. In the case of membership in the European Union, an additional national referendum is necessary, although with a reduced turnout (Article 79). Rather than the $50 \%$ threshold for constitutional amendment referendums, only half of the turnout rate of the previous parliamentary elections was needed for

\footnotetext{
49 Albi, EU Enlargement and the Constitutions of Central and Eastern Europe (n 9) 87.

50 On Lithuanian amendments related to specific EU related matters, see below Part IV.

51 Albi, EU Enlargement and the Constitutions of Central and Eastern Europe, (n 9) 98-103. The proposal of the European Law Department of the Government of Lithuania are reprinted in V Vadapalas, 'Lithuania: The Constitutional Impact of the Enlargement at National Level' in Kellermann, De Zwaan and Czuczai (eds), EU Enlargement (n 8) 347, 366-368.

52 Article 1 of the Constitutional Act reads: The Republic of Lithuania as a Member State of the European Union shall share with or entrust to the European Union competencies of its State institutions in the spheres provided for in the founding Treaties of the European Union and to the extent that, together with the other Member States of the European Union, it could jointly meet its commitments in those spheres and could also enjoy the rights accorded by membership.'

53 For a discussion whether or not amendments to these articles were necessary, see A Usacka, 'The Impact of the European Integration Process on the Constitution of Latvia' in Kellermann, De Zwaan and Czuczai (eds), EU Enlargement (n 8) 337, 340-341.
} 
the accession referendum. On 20 September 2003, a majority of $67.44 \%$ of the voters participating in the polls $(72.53 \%)$ voted in favour of EU accession. The Latvian Parliament ratified the Accession Treaty on 2 October 2003 with a large majority (out of 95 votes cast, 91 were in favour and 4 against).

Finally, Estonia underwent a rather special procedure. Under Article 1 of the Constitution, Estonian independence and sovereignty are 'interminable and inalienable'. A government commission came to the conclusion to amend this article and to insert a new delegation of power clause to allow for EU membership. ${ }^{54}$ However, under Chapter XV of the Constitution, a referendum would have been obligatory for amending provisions in Chapter I, including those on sovereignty and independence; 'ordinary' amendments relating to provisions in other Chapters would have to be supported by a majority of all deputies and by the succeeding Parliament with a three-fifths majority. Given the procedural constraints involved, it was decided after heated political discussions not to formally touch the text of the Constitution itself. Rather, on 18 December 2002, the Riigikogu (Parliament) adopted the Third Constitutional Act to supplement the Constitution. Under Articles 1 and 2 of this Act, Estonia belongs to the European Union and applies its constitution, taking into account the rights and obligations deriving from the Accession Treaty. Article 3 contained the following question: 'Are you in favour of the accession to the European Union and passage of the Act on Amendments to the Constitution of the Republic of Estonia?' In the referendum of 14 September 2003, 64.06\% of Estonian voters participated. A majority of $66.8 \%$ voted in favour of the constitutional amendment and at the same time for accession. ${ }^{55}$ This paved the way for the unanimous ratification of the Accession Treaty by Estonia by the Parliament on 21 January 2004, after the National Court had declared nine cases against the referendum to be inadmissible on procedural grounds. ${ }^{56}$

\footnotetext{
54 T Kerimäe, 'Estonian Constitutional Problems in Accession to the EU' in Kellermann, De Zwaan and Czuczai (eds), EU Enlargement (n 8) 291, 295-297.

55 Albi, EU Enlargement and the Constitutions of Central and Eastern Europe (n 9) 90.

56 Albi, EU Enlargement and the Constitutions of Central and Eastern Europe (n 9) 92 with further references.
} 
c) Poland, Czech Republic, Slovakia, Hungary, Slovenia

Article 90 of the Polish Constitution of $1997^{57}$ entails a choice for the legislature. The delegation of powers could either be adopted in Parliament, requiring a two-thirds majority in both chambers (Sejm and Senate), or consent for ratification could be given by a nationwide referendum. On 17 April 2003, the Sejm decided for the latter option. ${ }^{58}$ According to the referendum law of 14 March $2003,{ }^{59}$ a turnout of at least $50 \%$ was needed for a binding vote. In the referendum of $7-8$ June, $58.85 \%$ of voters cast their vote, and a majority of $77.45 \%$ voted for EU accession. Poland deposited its ratification act to the Accession Treaty on 5 August 2003.

In Slovakia, a comprehensive constitutional reform with altogether 85 amendments was adopted by Parliament in February 2001. ${ }^{60}$ Rather than resorting to the old Article 7 on 'union with other states', ${ }^{61}$ the new Article 7 (2) allows for the transfer of the exercise of competences to the European Union. ${ }^{62}$ Such a transfer requires a three-fifths majority in Parliament (Article 84 (4)). In addition, referendums can be held on 'important issues of public interest' or on joining 'state alliances' (Article 93 (2) and (1)). While the latter provision envisaged potential decisions over a closer relationship with the Czech Republic, the former was used prior to EU accession. On 16-17 May 2003 the people were asked whether they would agree with Slovak EU membership. The slim passing of the 50\%

57 Article 90 of the Polish Constitution reads: '(1) The Republic of Poland may, by virtue of international agreements, delegate to an international organisation or international institution the competence of organs of State authority in relation to certain matters. (2) A statute, granting consent for ratification of an international agreement referred to in para. 1, shall be passed by the Seim by a two-thirds majority in the presence of at least half of the statutory number of Deputies, and by the Senate by a two-thirds majority in the presence of at least half of the statutory numbers of Senators. (3) Granting of consent for ratification of such agreement may also be passed by a nationwide referendum in accordance with the provisions of Article 125. (4) Any resolution in respect of the choice of procedure for granting consent to ratification shall be taken by the Sejm by an absolute majority vote taken in the presence of at least half of the statutory number of Deputies.'

58 Uchwala Sejmu Rzeczypospolitej Polskiej z dnia 17 kwietnia 2003 r. Dz.U. Nr. 66 pz. 613 (2003).

59 Ustawa z dnie 14 marca 2003 r. Dz.U. Nr. 57, pz. 507 (2003).

60 Constitutional Act No 460/1992. For details, see Albi, EU Enlargement and the Constitutions of Central and Eastern Europe (n 9) 67-70.

61 In Slovakia there was considerable debate whether it would be appropriate to resort to that Article. See V Kunová, 'Constitutional Aspects of the Accession of the Slovak Republic to the European Union' in Kellermann, De Zwaan and Czuczai (eds), EU Enlargement (n 8) $327,328$.

62 Article 7 (2) of the Slovak Constitution stipulates: 'The Slovak Republic may, by an international treaty, which was ratified and promulgated in the way laid down by law, or on the basis of such treaty, transfer the exercise of a part of its powers to the European Communities and the European Union. (...).' 
threshold (52.15\% turnout) was - politically - compensated by the high number of positive votes (93.71\%). Against the background of this popular support, the Slovak Parliament adopted on 1 July 2003 the Act of Ratification to the Accession Treaty with 129 votes in favour out of 140 .

In the Czech Republic, the government proposed several times to Parliament to modify the national Constitution in view of EU accession. A modest amendment was finally adopted in the House of Representatives (July 2001) and the Senate (October 2001) and entered into force on 1 June 2002. ${ }^{63}$ According to the new Article $10 a,{ }^{64}$ a treaty delegating powers to international institutions must either be ratified by a majority of three-fifths in both houses of Parliament or by a referendum. A total of $55.18 \%$ of the population went to the polls on 13-14 June 2003, and there was a majority of $77.33 \%$ voting in favour of EU accession. Against that background, the Czech president signed the ratification bill into law on 30 September 2003.

In Hungary, where a two-thirds majority in Parliament is needed to change the constitution, the four parliamentary groups agreed on a constitutional modification in December 2002. ${ }^{65}$ Article 2A on joint exercise of powers in the European Union ${ }^{66}$ necessitates a two-thirds majority in Parliament for the ratification of the Accession Treaty. In addition, the need to hold a national referendum on EU accession was specifically laid down in Article 79 of the Constitution. ${ }^{67}$ In the popular vote of 12 April

\footnotetext{
63 Constitutional Act No 395/2001 Coll.

64 Article 10a of the Czech Constitution reads: '(1) Certain powers of constitutional institutions can be transferred by an international treaty to an international organization or institution. (2) Such a treaty must be ratified by both chambers of the Parliament unless a constitutional act requires that such ratification needs the approval by referendum.'

Article 39 (4) reads: 'For the adoption of a constitutional act or the ratification of an international treaty referred to in Article 10a, a 3/5 majority of all deputies and a 3/5 majority of present Senators is required.'

65 Act No LXI/2002. For more details on the Hungarian reform, see J Czuczai, 'Constitutional Preparation for EU Accession' (n 9) 278-283.

66 Article 2 A of the Hungarian Constitution reads: '(1) By virtue of a treaty, the Republic of Hungary, in its capacity as a Member State of the European Union, may exercise constitutional powers jointly with other Member States to the extent necessary in connection with the rights and obligations conferred by the treaties on the foundation of the European Union and the European Communities (hereinafter referred to as "European Union"); these powers may be exercised independently and by way of the institutions of the European Union. (2) The ratification and promulgation of the treaty referred to in Subsection (1) shall be subject to a two-thirds majority vote of the Parliament.'

67 Article 79 of the Hungarian Constitution reads: 'A peremptory national referendum shall be held concerning the accession of the Republic of Hungary to the European Union under the conditions laid down in the accession treaty. The date of this referendum will be 12 April 2003. The question of the referendum shall read as follows: "Do you agree that the Republic of Hungary should become a member of the European Union?"”
} 
$2003,{ }^{68}$ the turnout of $45.59 \%$ was the lowest in all the new Member States. However, as no threshold existed, a majority of $83.76 \%$ of votes in favour created the legal prerequisite for an act of ratification. The Hungarian Parliament actually ratified the Accession Treaty unanimously on 17 December 2003. ${ }^{69}$

On 7 March 2003, the Slovenian Parliament amended the national constitution, easily reaching the necessary two-thirds majority as required by Articles 168-171 of the Slovenian constitution. It inserted with Article $3 a$ of the constitution ${ }^{70}$ a clause on the transfer of the exercise of part of its sovereign rights to international organisations. A ratification law must be adopted by a two-thirds majority in Parliament. In addition, Parliament may call a referendum before ratifying the agreement. Indeed, the Slovene people were invited to vote on 23 March 2003, and 60.23\% cast their vote. In total, $89.61 \%$ voted for EU accession. The parliamentary ratification bill on the Accession Treaty was passed with 80 votes out of 84 on 28 January 2004.

\section{d) Bulgaria and Romania}

Both Bulgaria and Romania underwent 'remarkably comprehensive $^{{ }^{71}}$ constitutional reforms prior to their EU accession.

A constitutional amendment of 18 February 2005 introduced a number of innovations into the Bulgarian Constitution of 1991. A new Article 4 (3) stipulates that the Republic of Bulgaria shall participate in the construction and development of the European Union. The new Article 85 (1) point 9 empowers the National Assembly to ratify international

68 Note that the date of 12 April 2003 was deliberately chosen to be prior to the signing of the Accession Treaty. The Hungarian Government advocated this sequence of events to have the full backing of the Hungarian people before proceeding to sign, instead of running the risk of signing followed by a possibly negative referendum result which would seriously damage the government's credibility. See the speech of Foreign Minister Kovacs before the Hungarian Parliament on 15 November 2002 <www.parlament.hu/biz/europa/ angol/menu/index_1.htm>.

69 Parliamentary Resolution No 133/2003 (XII.17).

70 Article 3a of the Slovenian Constitution reads: ‘(1) Pursuant to a treaty ratified by the National Assembly by a two-thirds majority vote of all deputies, Slovenia may transfer the exercise of part of its sovereign rights to international organisations which are based on respect for human rights and fundamental freedoms, democracy and the principles of the rule of law and may enter into a defensive alliance with states which are based on respect for such values. (2) Before ratifying an international treaty referred to in the preceding paragraph, the National Assembly may call a referendum. A proposal shall pass at the referendum if a majority of voters who have cast valid votes vote in favour of such. The National Assembly is bound by the result of such referendum. If such referendum has been held, a referendum regarding the law on the ratification of the treaty concerned may not be called. (3) ...(4) ...'

71 A Albi, 'Impact of European Integration on National Constitutions and Parliaments' in Kellermann, Czuczai and others (eds), Impact of EU Accession (n 8) 243, 265. 
treaties which confer to the European Union powers ensuing from the Constitution with a two-thirds majority of all Members of Parliament. As these amendments did not fall within the reserved powers of the Grand National Assembly (a specifically convened body to decide upon fundamental constitutional changes), ${ }^{72}$ the ordinary National Assembly decided on them with a three-quarters majority (Article 155 of the Constitution). Based on these new constitutional provisions, the Accession Treaty of 25 April 2005 was ratified by the Bulgarian Parliament on 11 May 2005 with an overwhelming majority of 231 out of 234 Members of Parliament.

In Romania, the starting point was different. Under Article 147 (3) of the Constitution, any revision needs to be approved by a national referendum. Furthermore, by virtue of Article 152, no constitutional amendment may touch upon the national, independent, unitary, and indivisible character of the Romanian State; the Republican form of government; territorial integrity; independence of the judiciary; political pluralism and the official language. Against this background, the Romanian Constitutional Court was asked whether a legislative proposal for an amendment to the Constitution could foresee the transfer of powers to the European Union. In Decision No 148 of 16 April 2003, the Court confirmed the constitutionality of the proposal by arguing, inter alia, that the sharing of the exercise of sovereign attributes with other states does not confer on the EU 'competence over competence', ie its own sovereignty. Furthermore, the concept of national sovereignty could no longer be conceived as absolute and indivisible, 'without taking the risk of acknowledging an unacceptably isolated position'. ${ }^{73}$ After the Court had thus paved the way, the amendments were put to the people in October 2003. With a participation level of $54 \%$, over $80 \%$ of voters agreed, along with another thirty or more amendments, to anchor a new title VI into the Romanian Constitution entitled 'Euro-Atlantic integration'. The new Article $148(1)^{74}$ provides that Romania's EU accession can be passed by a two-thirds majority in both Houses of Parliament. In fact, both the Chamber of Deputies and the Senate adopted unanimously the ratification bill for the Accession Treaty on 18 May 2005, with all 434 parliamentarians voting in favour.

\footnotetext{
72 Decision of the Bulgarian Constitutional Court, 10 April 2003, reported in E Tanchev, 'Constitutional Amendments Due to Bulgarian Full EU Membership' in Kellermann, De Zwaan, Czuczai (eds), EU Enlargement (n 8) 308.

73 Constitutional Court of Romania, Decision No 148, OJ 171, Part I, No 317, cited in V Dudulescu, R Adam, 'Romania' in Kellermann, Czuczai and others (eds), Impact of EU Accession (n 8) 113, 119, n 10.

74 Article 148 of the Romanian Constitution reads: 'Romania's accession to the constituent treaties of the European Union, with a view of transferring certain powers to Community institutions, as well as to exercising in common with other Member States the abilities stipulated in such treaties, shall be carried out by means of a law adopted in the joint sitting of the Chamber of Deputies and the Senate, with a majority of two thirds of the number of deputies and senators.'
} 


\section{Analytical comparison}

For the purpose of this rough overview, we may briefly compare the main theoretical differences relating to the ratification procedures of the now 27 Member States and their practical impact.

\section{a) Theoretical models}

A few States apply their constitutional provisions as regards the ratification of international treaties irrespective of the special nature of the European Union. However, in these States the parliamentary act of ratification takes account of the need to ensure primacy of Community law, as is the case in the United Kingdom and Malta. In Finland, the absence of a specific constitutional basis for EU membership is compensated by the fact that a constitutional majority was needed to adopt the Accession Act. In Lithuania and Cyprus, the special constitutional significance of EU membership was recognised shortly after accession by the passage of specific EU integration clauses. While reasons for such delay are unclear in Lithuania, ${ }^{75}$ in Cyprus the special circumstances of parallel EU accession and UN mediation on the Cyprus problem provided a unique context.

In another group of States, the predominant idea is the limitation of sovereignty. In the old Member States, such language was originally present in the Constitutions of France and Italy. It also found its way into the Greek Constitution, which, however, also at the same time embodies the concept of transfer of powers. On the one hand, this construction appears to reconcile easily with other constitutional provisions on sovereignty. When sovereignty is only limited, then there can be no doubt that it is still vested in the people as the souverain. Accordingly, any allegation that EU membership would undermine the sovereignty of the State can easily be discarded under such a model, and EU membership becomes possible without prior constitutional amendments on sovereignty. ${ }^{76}$ On the other hand, this concept is not particularly in fashion any more. In France, a new clause on joint exercise of powers was added in 1992, but this model cannot be found in any of the new Member States.

Another idea is contained in the expression transfer of powers, as used in the old Member States of Germany, the Netherlands, Denmark, and Sweden. Here, the constitutional legislator makes the point that certain powers are no longer vested in the State institutions. Rather, they are transferred to an international organisation or the European Union.

75 I Jarukaitis, 'Lithuania' in Kellermann, Czuczai and others (eds), Impact of EU Accession (n 8) 385, 395.

76 De Witte (n 10) 68. 
These entities then enjoy constitutional legitimacy by the very fact that their powers were attributed through a special procedure. While not being explicit, the notion of transfer of power may also imply that the respective power is waived at national level. ${ }^{77}$ In Denmark and Sweden, the act is described as delegation which entails the legal connotation of transfer from a superior to an inferior level. ${ }^{78}$ Among the new Member States, Latvia, Poland, the Czech Republic all joined this group with a preference for using the term delegation rather than transfer of powers; in contrast, Bulgaria is closer to the German and Dutch terminology.

A fourth group of States speaks of common exercise of powers. Such wording is common in the old Member States of Luxemburg, Belgium, Spain, Portugal, and France (since 1992). Under this model, the power remains in the State institution, but may also be exercised by another level of governance. The State therefore still enjoys the constitutional power to adopt national measures in relevant policy areas of the European Union, but has agreed that such measures need to be compatible with the law of the latter. An exercise of powers clause can also be interpreted as requiring the supremacy of Community law to have its limits in the basic principles and values of the Constitution, as did the Spanish Constitutional Court in its Opinion on the Treaty establishing a Constitution for Europe with respect to the Spanish clause. ${ }^{79}$

This model has also attracted the new Member States of Slovakia and Slovenia. Moreover, in Hungary, the Parliament deliberately modified the wording 'delegation of powers' used in the government bill, which was perceived by the opposition parties as being too far reaching, into 'jointly exercise certain powers with other Member States'. ${ }^{80}$ This Hungarian clause also uses the remarkable limitation that such joint exercise is only desired 'to the extent necessary' for compliance with European law. Romania is another interesting example, where both the transfer of powers to Community institutions and the common exercise of powers are mentioned in the same provision.

Finally, certain States directly combined EU accession with constitutional modifications. This technique was witnessed first in Ireland.

77 J Zemánek, 'Czech Republic' in Kellermann, Czuczai and others (eds), Impact of EU Accession (n 8) 313, 317.

78 H. Koch, 'The Danish Constitutional Order' in Kellermann, De Zwaan, Czuczai (eds), EU Enlargement (n 8) 109, 110; A Usacka, 'Latvia' in Kellermann, Czuczai and others (eds) Impact of EU Accession (n 8) 369, 382.

79 Constitutional Court of Spain, Opinion on the consistency of the European Constitutional Treaty with the Spanish Constitution, DTC 1/2004, 13 Dec 2004 with commentary by F Castillo de la Torre, 42 CMLRev (2005) 1169.

80 J. Czuczai, 'Hungary' in Kellermann, Czuczai and others (eds), Impact of EU Accession (n 8) 343, 344 n 5. 
Austria, with its unique model of 'total revision', provides for another example, as does Estonia from the new Member States where an Act Supplementing the Constitution was adopted, a category not previously foreseen in the Constitution.

\section{b) Practical impact}

With these theoretical differences in mind, a comparison of the practical ratification requirements reveals that there are basically three different levels.

In the Member States which apply their constitutional provisions as regards ratification of international treaties, no additional procedural requirements have to be met. Usually, a simple majority in Parliament is sufficient. The same is true for some 'limitation of sovereignty' countries, such as France and Italy or, exceptionally, a country with a 'common exercise of powers' clause, such as Portugal. However, if the treaty contains certain provisions with constitutional impact, the situation becomes more complicated. Then, prior constitutional amendments must be adopted through a complex procedure, as happened in France and Portugal in 1992.

The Member States with a 'transfer of powers' or a 'common exercise of powers' clause have grown continuously over time and represent a large majority today. With the exception of Portugal, the use of such clauses entails considerable procedural consequences. Either the quorum in Parliament increases (Luxemburg, Netherlands, Germany, Greece, Spain, Sweden, Bulgaria, or Romania) or the possibility arises to hold a binding referendum. The latter possibility was traditionally used only in Denmark by way of constitutional custom. However, more recently, recourse to referenda has also been exercised in a number of new Member States, either in addition (Latvia, Slovakia, Hungary, and Slovenia) or as an alternative (Poland, Czech Republic) to the parliamentary vote.

Austria, Ireland and Estonia applied the most cumbersome - and very distinct - procedures to bring about their respective EU membership. Ireland inserted an amendment to its constitution, necessitating a referendum. Austria, for its part, combined a very cumbersome procedure to totally revise its Constitution through EU accession in 1995, not fitting into any model. Estonia combined a constitutional revision together with a referendum on accession by putting two distinct questions to the people.

\section{Domestic Rank of Community law}

The above-mentioned theoretical and practical differences in the ratification procedures also have an impact on the domestic rank of Community law. 


\section{Member States with ratification procedures relating to international treaties}

In the old Member States, the constitutional provision on the rank of international treaties also determines the internal rank of Community law.

In Finland, there is no constitutional provision on the rank of international treaties in the national system. Since Finland is a traditionally dualist country, treaties would gain the same rank as the national act whereby they are incorporated. ${ }^{81}$ However, as the Accession Act was adopted by a law adopted with a constitutional majority in Parliament, this provided the Supreme Administrative Court with a basis to accept the supremacy of Community law over Finnish statutes. ${ }^{82}$ Whether that would also extend to the Constitution itself has not been tested yet; 83 furthermore, the new Article 94 (3) of the Constitution, according to which an international obligation shall not endanger the democratic foundation of the State, may well be used as a constitutional reserve at some stage. In the United Kingdom, where a written constitution with the highest normative rank is missing, the European Communities Act transposes European law into British law with the rank of a statute. Nevertheless, as can be drawn from the ECA, any subsequent British Statute shall be construed in a way that conforms to the obligations arising under EC law. Theoretically, the situation could arise that a statute adopted later in time runs deliberately contrary to EC law. In such a situation, the British law would have to be applied, as Lord Denning held in the famous case Macarthys $v$. Smith. ${ }^{84}$ Or, the ECA could be interpreted as a voluntary self-limitation of Parliament, as Lord Bridge held in Factortame (No. 2). ${ }^{85}$ However, as the latter view was not endorsed by the other Lords, the British situation remains open to future developments. ${ }^{86}$

The situation is less clear in the new Member States. International treaties become part of Maltese law when they are incorporated by an Act of Parliament. The Act may also determine its relationship with other Maltese statutes. Inspired by the model of Act XIV on the European Convention, section 3 (2) of the European Union Act of 16 July 2003

\footnotetext{
81 Antero Jyränki, Uusi perustuslakimme (Turku, 2000) 73-74. See also Article 94 of the new Finnish Constitution cited above.

82 Supreme Administrative Court, 31 December 1996, KHO 1996 B 577.

83 Griller (n 35) 167-168.

84 [1979] 3 All ER 325.

85 [1991] AC 603, at 658.

86 A Dashwood, 'The British Way: The Cohabiting with Community Law' in Kellermann, de Zwaan, Czuczai (eds) (n 8) 81, 87.
} 
provides for the supremacy of Community law over other Maltese laws; ${ }^{87}$ furthermore, Article 65 of the Maltese Constitution, as amended, makes European law supreme over any subsequent law passed by the Maltese Parliament, with the effect that no lex posterior rule could apply. ${ }^{88}$ On the other hand, given the fact that Section 6 of the Maltese Constitution on the supremacy of the Constitution remained deliberately intact, it is likely that European law will not supersede the Constitution itself.

In Cyprus, the starting point was quite similar. Certain international treaties become applicable in Cyprus if ratified by an Act of Parliament and published in the Official Gazette. Under Article 169 (3) they prevail over 'municipal law'. Cypriot jurisprudence ${ }^{89}$ specifies that this principle does not touch upon the supremacy of the Constitution laid down in Article 179 (1) of the Constitution. Rather, the term 'municipal law' in Article 169 (3) refers to ordinary statutes and regulations. Hence, ratified international treaties enjoy a rank over other statutes, but below the Constitution. The EU Accession Act did not change this situation. Under Section $4,{ }^{90}$ the Treaty of Accession only supersedes other legislative or regulatory acts. The shortcomings of this approach, however, soon became apparent in a case involving a Cypriot citizen whose transfer to the UK was demanded by British authorities according to the European Arrest Warrant. ${ }^{91}$ As Article 11 of the Cypriot Constitution contained a provision according to which Cypriot citizens cannot be extradited, the Supreme Court of Cyprus confirmed the non-extradition of the person. That decision was in conformity with Cypriot law, but in defiance of EU law. Thereafter, on 28 July 2006, the (Greek Cypriot members ${ }^{92}$ of the)

87 Section 3 of Act V 2003, the Maltese European Union Act, provides: '(1) From the first day of May 2004, the Treaty and existing and future acts adopted by the European Union shall be binding on Malta and shall be part of the domestic law thereof under the conditions laid down in the Treaty. (2) Any provision of any law which from the said date is incompatible with Malta's obligations under the Treaty or which derogates from any right given to any person by or under the Treaty shall to the extent that such law is incompatible with such obligations or the extent that it derogates from such rights be without effect and unenforceable.'

88 PG Xuereb 'Malta' in Kellermann, Czuczai and others (eds), Impact of EU Accession (n 8) 409, 411.

89 See Eracleous v.The Municipality of Limassol (Appel No 5793) Judgment of the Supreme Court of 14 December 1993.

90 Section 4 of the EU Accession Act (Law 4(III)/2003) states: 'The rights and obligations imposed by the Treaty shall have direct effect in the Republic and supremacy over any legislative or regulatory act providing to the contrary.'

91 Framework decision No 2002/584/JHA of 13 June 2002 on the European arrest warrant and other surrender procedures between Member States, OJ 2002, L 190, 1.

92 Under Article 182 of the Cypriot constitution, amendments need to be approved by a majority vote comprising at least two-thirds of the total representatives belonging to the Greek Cypriot community and at least two-thirds of the number of Representatives belonging to the Turkish Cypriot community. However, the Supreme Court of Cyprus accepted 
House of Representatives passed a constitutional amendment. ${ }^{93}$ Under the new Article 1a) of the Cyprus Constitution, none of its provisions prevent Regulations, Directives or other acts or binding measures of a legislative nature enacted by the European Union or by the European Communities or by their institutions or bodies from having legal force in the Republic.

Finally, under Article 138 (3) of the Lithuanian Constitution, international agreements which are ratified by Parliament shall be a constituent part of the national legal system. The Constitutional Court clarified in 1995 that they would have to be applied 'in the same way as legislation'. ${ }^{94}$ Whereas this dictum could have opened the door for a lex posterior situation, Article 11 (2) of the Law on International Treaties, as amended in 1999, established that international treaties enjoy priority over laws and other legal acts of the Republic. While that rule applies to all international treaties, the same result is now expressly foreseen for European law under Section 2 of the EU Constitutional Act of 2004. ${ }^{95}$ However, since the Constitution is not mentioned, the principle of constitutional supremacy as laid down in Article 7 (1) of the Lithuanian Constitution appears to be still in place also with regard to European law. ${ }^{96}$

\section{Member States with limitation of sovereignty clauses}

In Italy, Article 11 of the Constitution provided the Italian courts with a basis to recognise the supremacy of Community law over national legislation over time. ${ }^{97}$ However, when it comes to constitutional law, the Italian Constitutional Court keeps a fundamental reserve on the protection of human rights. ${ }^{98}$ In Greece, case law accepts the supremacy of

that amendments can be passed in the absence of Turkish Cypriot Representatives on the basis of the doctrine of necessity. For more details, see C Patsalides, 'Accommodating the Principle of Supremacy of Community Law to the Cypriot Legal Order - the Necessity for a Constitutional Amendment', 12 European Public Law (2006) 363, 368-370.

93 The Fifth Amendment to the Constitution Act of 2006, No 127 (I) 2006 of 28 July 2006.

94 Constitutional Court of Lithuania, Opinion of 24 January 1995, No 9-199.

95 Article 2 of the Constitutional Act of 13 July 2004 reads: 'The norms of the acquis of the European Union shall be an integral part of the legal order of the Republic of Lithuania. Where it follows from the founding Treaties of the European Union, the norms of the acquis shall apply directly, while in the event of a conflict between legal norms, the norms of the acquis shall prevail over the laws and other legal acts of the Republic of Lithuania.'

96 I Jarukaitis (n 75) 394.

97 Corte Costituzionale, Granital/Amm. Finanze, no 170-1984, Giurisprudenze costituzionale 1984, 1098, 5.6.1984. For more details, see M Cartabia, 'The Italian Constitutional Court and the Relationship between the Italian Legal System and the European Union' in A-M Slaughter, A Stone Sweet and JHH Weiler (eds), The European Court \& National Courts - Doctrine and Jurisprudence (Oxford, Hart Publishing 1998) 133ff.

98 See the decision of the Italian Constitutional Court, Fragd/Ammin. Finanze, No 232 of 21.4.1989, Rivista di diritto internazionale, 1989, 103, commented by Henry G. Scherm- 
Community law over Greek statutes by virtue of Article 28 of the Constitution; ${ }^{99}$ however, doctrine is divided whether such supremacy would also extend to constitutional law itself. ${ }^{100}$

\section{Member States with transfer or delegation of powers clauses}

In the large second group of Member States, respective constitutional clauses allowing for a transfer or delegation of powers determine the internal rank of Community law as follows.

In the Netherlands, Article 94 of the Constitution provides that supranational law enjoys precedence over national law. ${ }^{101}$ In Germany, both the old general transfer of powers clause (Article $24 \mathrm{GG}$ ) and the new Europe clause (Article $23 \mathrm{GG}$ ) have been interpreted to allow for the supremacy of Community law domestically. ${ }^{102}$ However, the German Constitutional Court also reserved its right to reject the application of Community law as supreme if the protection of human rights in the Community legal order would fall short of a standard that is essentially comparable to the national standard. ${ }^{103}$ In Denmark, neither Paragraph 20 of the Constitution nor the Danish Act of Accession addresses the issue of supremacy, although the doctrine was known and recognised in parliamentary debates in 1972. ${ }^{104}$ The Danish Constitutional Court did not take a stance on this question either, but underlined that a piece of Community law could be inapplicable in Denmark if the Community had transgressed its delegated powers and the issue was not satisfactorily resolved by the European Court of Justice. ${ }^{105}$ The Swedish jurisprudence acknowledges the supremacy of Community law over statutes and the Constitution it-

ers: 'The Scales at Balance, National Constitutional Court v. Court of Justice' 27 CMLRev (1990) 97-105.

99 Council of State Decision 2152/1986. See for more details V Cristianos, 'Les juridictions helléniques face à la primauté du droit communautaire’ 6 RFDA (1990) 969, 972 with further references.

100 K Chryssogonos, 'The European Union and the Greek Constitutional Order' in Kellermann, De Zwaan and Czuczai, EU Enlargement (n 8) 141, 142.

101 Article 94 of the Dutch constitution.

102 Constitutional Court Decisions (BVerfGE) 22, 293 (296); 31, 145 (173). For a discussion of the constitutional situation in Germany, see I Pernice, 'Article 23 GG, Commentary' in H Dreier (ed) Grundgesetz-Kommentar, (Tübingen 2006) paras 27-32.

103 Decision of the German Constitutional Court of 1991 (BVerfGE 89, 155 - Maastricht) and decision of 7 June 2000 (Bananas), commented by F. Hoffmeister, 38 CMLRev (2001) 791; the Swedish Constitution (Chapter 10, $§ 52^{\text {nd }}$ sentence) contains a similar reserve in regard to human rights standards.

104 Koch (n 78) 112.

105 Decision of the Danish Supreme Court of 6 April 1998 - Maastricht, with German translation in EuGRZ 1999, 50 et seq and commentary by F Thomas, 'Das 'Maastricht-Urteil des dänischen Obersten Gerichtshofs vom 6. April 1998’ 58 ZaöRV (1988) 879-906. 
self; ${ }^{106}$ however, as Chapter 10 , Article 5 also includes the requirement that the transfer of powers should be compatible with the protection of fundamental rights, it is not excluded that a constitutional reserve may be activated at some stage in this field if the Community standards were perceived to fall short of them.

According to Article 91 (3) of the Polish constitution, ${ }^{107}$ the laws established by an international organisation to which Poland has transferred powers shall have precedence in the event of a conflict of laws if the agreement establishing the international organisation so provides. As this provision does not go so far as to accept the precedence of European law over Polish constitutional law, the constitutionality of European law may be put at stake before the Polish Constitutional Court. ${ }^{108}$ Indeed, in the decision of 11 May 2005 on the Accession Treaty, ${ }^{109}$ the constitutional justices verified whether the Accession Treaty and the Founding Treaties were consistent with the Polish Constitution. They found that the delegation of competences to an international organisation may not be contrary to the Constitution being the supreme law of the Republic according to its Article 8. If there was a conflict between a Community norm and the Polish Constitution, the Nation as the sovereign would have to decide on amending the Constitution, or on causing modifications within Community provisions or, ultimately, on Poland's withdrawal from the EU. ${ }^{110}$ Nevertheless, the Court also emphasised that one could not simply apply Polish constitutional law to assess the specifics of the Community legislative system. ${ }^{111}$ Accordingly, Community law cannot be challenged as unconstitutional because of the genuine Community decision-making system. Rather, the constitutional reserve could only become valid with respect to substantive issues of Community law. Where there are no fundamental doubts in this regard, Polish Courts are obliged not to apply national statutes that violate directly applicable Community law. Preliminary references on such conflicts should be directed to the Euro-

\footnotetext{
106 Supreme Administrative Court, Judgment of 25 November 1997, Case 219/97, Lassagard.

107 Article 91 (3) of the Polish Constitution reads: 'If an agreement, ratified by the Republic of Poland, establishing an international organisation so provides, the laws established by it shall be applied directly and have precedence in the event of a conflict of laws.'

108 W Czaplinski, 'L'intégration européenne dans la constitution polonaise de 1997' Revue du Marché Commun (2000) 168, 172.

109 Constitutional Tribunal, Judgment of 11 May 2005, K 18/04, English translation available at <http://www.trybunal.gov.pl/eng/summaries/wstep_gb.htm>

110 Ibid para 13.

111 Ibid para 21: 'The formal requirements for adopting Polish law, as specified in the Polish constitution are not directly applicable to the procedures and principles governing the adoption of Community law.'
} 
pean Court of Justice, and not to the Polish Constitutional Tribunal, as the latter has confirmed recently. ${ }^{112}$

The Czech experience points in the same direction. A government proposal on a new Article 10b of the Constitution, which foresaw supremacy over national law, including constitutional law, ${ }^{113}$ was not adopted in the Parliament. Rather, the modified Article 10 of the Czech Constitution only provides for supremacy over domestic statutes. ${ }^{114}$ Although the wording 'statute' (zakón) could refer to ordinary and constitutional statutes (ustauni zakón) alike, the Czech Constitutional Court made it clear that EC law does not enjoy unfettered supremacy. In its decision on 'Sugar Quota II', ${ }^{115}$ the Court found in March 2006 that the conferral of powers to the EC was conditional. The original bearer of sovereignty, as well as the powers flowing therefrom, still remains the Czech Republic, whose sovereignty is still founded upon Article 1 (1) of the Czech Constitution. In the Court's view, the conditional nature of the delegation of these powers manifests itself in the function of the Court to protect constitutionalism (Article 83 of the Constitution). Therefore, the Court may verify whether the delegated powers are exercised in a manner that is compatible with the preservation and the foundations of state sovereignty of the Czech Republic, and in a manner that does not threaten the very essence of the substantive law-based State, given that the essentials of democracy are protected by Article 9 (2) of the Constitution even beyond the reach of the Constituent Assembly itself. However, on the facts of the case the Court did question that European institutions had touched upon those principles. Rather, the Court confirmed that the contested sugar regulation should not have been adopted by the government, given that a directly applicable Commission regulation had already covered the field.

112 Constitutional Tribunal, Procedural Decision of 19 December 2006, Ref No P37/05 <http://www.trybunal.gov.pl/eng/summaries/wstep_gb.htm>

113 Article 10b of the proposal to amend the Czech Constitution provided: 'The constitution and other constitutional rules, international treaties mentioned in Article 10, laws and regulations cannot be interpreted and applied inconsistently with obligations arising from the Czech membership in an international institution according to Article 10a.' For a discussion of this proposal, see J Zemanek, 'Auswirkungen des Gemeinschaftsrechts in der Tschechischen Republik nach ihrem Beitritt zur Europäischen Union' in Walter Hallstein Institut für Europäisches Verfassungsrecht (ed), Verfassungsrechtliche Reformen zur Erweiterung der Europäischen Union (Nomos 2000) 157ff.

114 Article 10 of the Czech Constitution provides: 'Published international treaties, whose ratification Parliament approved and which are binding on the Czech Republic, shall be part of the Czech legal order; if the international treaty provides for a difference to a statute, the international treaty applies.'

115 Czech Constitutional Court, Pl. US 50/04, Judgment of 8 March 2006. English translation available at <http://test.concourt.cz/angl_verze/doc/p-50-04.html> 
In Latvia, despite the introduction of a delegation of power clause in Article 68 of the Constitution, ordinary rules for the domestic application of international treaties seem to apply. Under Article 13 of the Latvian Law on International Treaties, and Article 16 of the Law on the Constitutional Court, international treaties figure above domestic statutes, but below the national Constitution. ${ }^{116}$ It remains to be seen whether judicial practice will alter this general rule as regards EC law in view of the special procedures in the course of EU accession (obligatory referendum plus adoption of the ratification bill with a constitutional majority).

The Constitution is more explicit in Bulgaria. Also after the introduction of Article 4 (3) on the participation of Bulgaria in the European Union and the transfer of power clause in Article 85 (3), the supremacy of ratified treaties is limited to national statutes under Article 5 (4). Moreover, the Constitution needs to be amended under Article 85 (3) before ratifying unconstitutional treaties. Finally, the Constitutional Court has the power to review the constitutionality of international treaties under Article 149 (1) count 4 of the Constitution; in practice, the Court has confirmed the supremacy of the Constitution over international treaties. ${ }^{117} \mathrm{~A}$ combined reading of these provisions and the practice of the Court suggest that Community law will be accorded a rank above national statutes, but below the Constitution. ${ }^{118}$

\section{Member States with common exercise of powers clauses}

In the old Member States, the common exercise of powers clauses are the constitutional basis for applying Community law with precedence over national statutes. Jurisprudence can be found to that effect in Belgium, ${ }^{119}$ Luxemburg, ${ }^{120}$ Portugal ${ }^{121}$ and Spain. ${ }^{122}$ The situation is less

116 See D Luters-Thümmel, 'International Agreements in the Legal Order of the Candidate Countries, Latvia' in A Ott, K Inglis (eds), Handbook on European Enlargement (Asser Press 2002) 267, 270-271.

117 Constitutional Court of Bulgaria, Decision 7 of 2 July 1992, Official Gazette (DV) $56 / 92$.

118 E Tanchev, 'Constitutional Amendments Due to Bulgarian Full EU Membership' in Kellermann, De Zwaan and Czuczai (eds) EU Enlargement (n 8) 301, 305.

119 Cour de Cassation, Arrêt du 27 mai 1971, Etat belge v Fromagerie franco-suisse Le Ski, JT, 1971, 471. See K Lenaerts, 'The Application of Community Law in Belgium' 23 CMLRev (1986) 253-286. The decision relates to former Article 25bis of the Belgian Constitution (today Article 34).

120 Conseil d'Etat, Affaire Bellion et consorts v Ministre de la Fonction Publique; 21.11.1984, Pasicrisie Luxemb. XXVI 174.

121 Moura Ramos (n 33) 136.

122 Tribunal Supremo, 28.4.1987 - Ar. 4499-; 17.4.1989 - AR. 4524 - ; 24.4.1990 - AR. 2747; 30.11.1990 - Noticias CEE Nr 83 (1991), 121. For more details, see G. Garzon Clariana, 'The Spanish Constitutional Order' in Kellermann, De Zwaan and Czuczai (eds), EU Enlargement (n 8) 121-125. 
clear when it comes to conflicts with constitutional law. Here, the common exercise of powers clause may seem apt for a Community-friendly solution, ${ }^{123}$ but this is open to interpretation. In a similar vein, French civil and administrative courts were prepared to provide for the supremacy of international law (including European law) over national statutes under Article 55 of the Constitution; ${ }^{124}$ more recently, the Conseil Constitutionnel referred to Article 88-1 on the common exercise of powers in the European Union as the legal basis for a constitutional duty to implement Community directives, unless they are contrary to an express provision of the French Constitution. ${ }^{125}$ Furthermore, in its decision on the Treaty establishing a European Constitution, the highest French judicial body held that several provisions of constitutional value enable France to participate in the creation and development of the European Union and that Article 88-1 acknowledges the principle of primacy of Union law; ${ }^{126}$ however, 'when commitments entered into for such purpose contain a clause running counter to the Constitution, call into question constitutionally guaranteed rights and freedoms or adversely affect the fundamental conditions of exercising national sovereignty, authorisation to ratify such measures shall require a prior revision of the Constitution. ${ }^{127}$ This recalls the French position to insist on constitutional supremacy over European law on the one hand, but to require on the other hand a prior constitutional adaptation in order to harmonise both legal orders.

In the Slovak Republic, the precedence of European law is established over national laws. Article 7 (2) second sentence of the Constitution provides for the supremacy of 'legally binding acts of the European Communities and the European Union'. ${ }^{128}$ In as much as that provision was only to cover secondary law, but not the founding treaties, ${ }^{129}$ the primacy of primary law would be guaranteed by Article 7 (5) of the Constitu-

${ }^{123} \mathrm{Cf}$, for example, the respective doctrine referred to by Moura Ramos for Article 7 (6) of the Portuguese Constitution (n 33) 136.

124 See Cour de Cassation, Cafés Jaques Vabres, Judgment of 24 May 1975, English translation in 2 CMLRev (1976) 336, and Conseil d'Etat, Nicolo, Judgment of 20 October 1989, English translation in 27 CMLRev (1990) 17.

125 Conseil Constitutionnel, Décision No 2004-496 DC of 10 June 2004 para $7<$ http:// www.conseil-constitutionnel.fr> and commentary by J. H. Reestman, 1 EuConst (2005) 302.

126 Conseil Constitutionnel, Décision No 2004-505 DC of 19 November 2004, paras 6 and 13 <http://www.conseil-constitutionnel.fr> and discussed by F. Mayer, 'Europarecht als französisches Verfassungsrecht' 39 Europarecht (2004) 921.

127 Ibid para 7.

128 Article 7 (2) second sentence of the Slovak Constitution stipulates: 'Legally binding acts of the European Communities and the European Union shall have precedence over the laws of the Slovak Republic.'

129 See M Slastan, 'Slovakia' in Kellermann, Czuczai and others (eds) Impact of EU Accession (n 8) 437, 444-445. 
tion relating to international treaties. In contrast, it follows from Article 125 (1) (a) of the Slovak Constitution on the powers of the Constitutional Court that that there is no supremacy of European law over the Constitution and constitutional laws. ${ }^{130}$

Similarly, Article 145 (1) of the Romanian Constitution explicitly accords supremacy of Community law over national statutes, but equally provides for a preliminary review of the constitutionality of treaties (Article 11 (3)). Once it has been found constitutional it can no longer be subject to an objection of unconstitutionality (Article 145 (3)). This suggests that Community law is posited between constitutional and statutory law.

In contrast, the new Article 3a (3) of the Slovene Constitution ${ }^{131}$ is more open to interpretation. As the text refers to the legal force of legal acts from international organisations to which Slovenia has transferred the exercise of parts of its powers 'in accordance with the legal regulations of the organisation', one may argue on the one hand that Slovene constitutional law provides for the supremacy of Community law over national statutory and constitutional law alike. On the other hand, the Slovenian Constitutional Court had found - prior to the amendment - that any conflict between the Constitution and an international treaty must be solved in favour of the Constitution. In order to ratify unconstitutional treaties, a prior amendment of the Constitution is necessary. ${ }^{132}$ When the view is taken that the new Article 3 a of the Constitution did not change the situation, ${ }^{133}$ the Slovene Constitution would also enjoy supremacy over the Treaty of Accession in line with that earlier jurisprudence. In a recent case, ${ }^{134}$ Article 3 a was invoked by an applicant to challenge a decision not to nominate him for the Eurojust Joint Supervisory Board as he did not meet the minimum age of 40 years set in domestic legislation. The Constitutional Court did not, however, decide on the interpretation of that clause, as there was no conflict between European law and the Slovenian legislation. As the Council decision itself of 28 February 2002 establishing Eurojust foresaw that each Member State appoints mem-

130 Slastan (n 129) 442.

131 Article 3a (3) of the Slovenian Constitution reads: 'Legal acts and decisions adopted within international organisations to which Slovenia has transferred the exercise of part of its sovereign rights shall be applied in Slovenia in accordance with the legal regulations of these organisations.'

132 Constitutional Court of Slovenia, Case No RM-1/97, Official Gazette No 40/97. The decision is available in English at <http://www.us.-rs.si/en/index.html $>$ para 12.

133 M Pogacnik, M Starman, P Vehar, 'Slovenia' in Kellermann, Czuczai and others (eds) Impact of Enlargement (n 8) 179, 185.

134 Constitutional Court of Slovenia, Case No U-I-120/04, Official Gazette No 82/2004. The case is reported by $\mathrm{J}$ Czuczai, 'Impact of European Integration on the Role and Functioning of the National Judiciary' in Kellermann, Czuczai and others (eds), Impact of EU Accession (n 8) 267, 270-271. 
bers 'in accordance with its legal system', the constitutional complaint was inadmissible.

Finally, the Constitution of Hungary keeps silent on the question of which rank to accord Community law as part of domestic law, despite the fact that Article 2A on the common exercise of powers was inserted. A government proposal of October 2002, according to which precedence over all Hungarian law would have been accepted, did not find sufficient support in Parliament. ${ }^{135}$ Rather, the bill of November $2002^{136}$ which Parliament passed with several amendments as Act No. LXI/2002 left the issue deliberately open, as the opposition party argued against the supremacy of European law over the Hungarian Constitution. ${ }^{137}$ The interpretation of the new Europe clause by the Hungarian Constitutional Court has thus become crucial. While the Court ignored the implications of European law in an early case of April 2004, ${ }^{138}$ it interpreted Article 2A in a landmark decision of 28 February $2006 .{ }^{139}$ The question before it was whether the National Election Board was right in rejecting a popular initiative to call upon Parliament to adopt a scheme under which at least half of the agricultural products traded in Hungary were to be produced in Hungary. While the Board argued that Parliament could not adopt such a scheme as it would be contrary to Article $2 \mathrm{~A}$ of the Constitution and the free movement of goods under Article $28 \mathrm{EC}$, the Court found that the power of Parliament to enact laws under Article 19 (3) was not restricted by Article 2A. This ruling seems to highlight the specific understanding of the common exercise of powers clause: competence to enact laws has not been totally given up in areas covered by Community law; rather, the clause would ensure that in the case of conflict, Community law would

135 The government had proposed inserting the following Article 2A (2) into the constitution: 'In the Republic of Hungary the community law and other accomplishments of the European Union shall be implemented in accordance with the accession acts to the European Union and the doctrines stemming from those.' See Draft Bill No 1114/2002, tabled on 15 October 2002.

136 Draft Bill No 1270/2002, tabled on 5 November 2002.

137 J Czuczai, 'Hungary' in Kellermann, Czuczai and others (eds), Impact of EU Accession (n 8) $343,346$.

138 The case is commented upon by R Uitz, 'EU Law and the Hungarian Constitutional Court: Lessons of the First Post-Accession Encounter' in Sadurski, Ziller and Zurek (eds), Après Enlargement (n 8) 41-64; A. Sajó, 'Learning Co-operative Constitutionalism the Hard Way: the Hungarian Constitution Court Shying Away from EU Supremacy' 2 Zeitschrift für Staats- und Europawissenschaften (2004) 351. For a discussion of this case in a broader context, see A Albi 'Supremacy of EC Law in the New Member States - Bringing Parliaments into the Equation of "Co-operative Constitutionalism"' 3 European Constitutional Law Review (2007) 55-62.

139 Constitutional Court Ruling No 10/2006 (II.28) and reported by J Czuczai, 'Ratification of the European Constitution in Hungary: Problems and Challenges' in A Albi and J Ziller (eds), The European Constitution and National Constitutions: Ratification and Beyond (Kluwer 2007) 29, 35-36. 
prevail over domestic statutes. However, the latter point has not yet been spelt out by the Hungarian Constitutional Court. Neither did the Court shed light on the domestic rank of Community law in another decision of 15 December 2006, where it was confronted with the direct applicability of the Community Working Time Directive 93/104. ${ }^{140}$ Accordingly, in the absence of any statement to the contrary, it appears that Hungarian judges would have to apply the Hungarian Constitution as the supreme law of the land for the time being, as laid down in its Articles 50 (3) and 77 .

\section{Member States with special constitutional procedures}

In Ireland, the special ratification procedure involving a referendum has led to a rather unique clause accepting the supremacy of European law. Under its Article 29 (4) (8), no provision of the Irish Constitution invalidates laws enacted, acts done, or measures adopted by the State which are necessitated by the obligations of membership of the European Union or of the Communities, or prevents laws enacted, acts done, or measures adopted by the European Union or by the Communities or institutions thereof from having the force of law. This is a rather generous acceptance of supremacy. In practice, there may only be debate on whether an Irish measure was 'necessary' to profit from constitutional immunity. ${ }^{141}$ In Austria, the very fact that EU accession entailed a total revision of the Constitution led to the rather straightforward supreme application of Community law over Austrian law by the Austrian Constitutional Court. ${ }^{142}$ Likewise, according to $\S 2$ of the Constitution of the Republic of Estonia Amendment Act, adopted by way of a referendum, the Constitution shall be applied with due regard to the obligations arising from the Accession Treaty. ${ }^{143}$ As the Accession Treaty is the basis for the supremacy of Community law, this provision could be read as accepting the latter's precedence over Estonian constitutional and statutory law, as indicated by the Chancellor of Justice in a Supreme Court Case of April 2005. ${ }^{144}$ Indeed, in its opinion of 11 May 2006, the Supreme Court's

\footnotetext{
140 Constitutional Court Ruling No 72/2006 (XII.25), discussed by A Raisz, 'Confronted with Direct Applicability of a Directive: the Hungarian Constitutional Court Before Challenges' in 4 Miskolc Journal of International Law (2007) 113-127, 124-125. The article is available online at <http://www.mjil.hu>

141 For further details, see Hogan (n 27) 93-97.

142 Verfassungsgerichtshof, B 1625/98, Judgment of 24 February 1999; reported by Griller (n 35) 153.

${ }^{143} \S 2$ of the Constitution of the Republic of Estonia Amendment Act stipulates: 'When Estonia belongs to the European Union, the Constitution of the Republic of Estonia shall be applied with due regard to the rights and duties arising from the Accession Treaty'

144 See below Section IV 1.
} 
constitutional chamber found that the Supplementing Act should be read together with the text of the Constitution, so that those parts of the Constitution that are incompatible with Community law cannot be applied. ${ }^{145}$ Accordingly, the Chamber found that the Draft Act Amending the Bank of Estonia Act to prepare the country's adoption of the Euro was constitutional, although Article 111 of the Estonian Constitution accords the exclusive right to issue Estonian currency to the Bank of Estonia.

\section{Analytical comparison}

With respect to the domestic status of Community law accorded by national constitutions, two levels should be distinguished: statutes and constitutional law.

In the overwhelming majority of Member States, the supremacy of Community law over domestic statutes is well established under their constitutional systems. Irrespective of different concepts such as limitation of sovereignty, transfer/delegation of powers, or common exercise of powers, specific integration clauses share the same basic function, namely to provide for a constitutional basis for EU membership and to allow for the reception of the primacy doctrine by the jurisprudence. ${ }^{146}$ This is particularly obvious where such clauses do not refer to international organisations in general, but specifically to the European Union, thereby taking account of the special characteristics of Community law. ${ }^{147}$ Having been inspired by different examples from the old Member States, most new Member States amended their constitutions and inserted new integration clauses. These clauses generally spelt out the supremacy of European law over domestic statutes; if not, this result can be inferred from the very function of these clauses. Even in those Member States which resort to constitutional clauses relating to the ratification of international treaties, conflicts are usually resolved in favour of Community law. Either the relevant tradition allows for the supremacy of international treaty law over national statutes anyhow (Finland), or special efforts are undertaken in favour of Community law in order to overcome the otherwise applicable lex posterior rule (UK and Malta).

Irrespective of the existence (or not) of a specific integration clause, all Member States face the question about how to accommodate the precedence of EC law over their national constitutional law. In this regard, three different models can be identified.

\footnotetext{
145 Opinion No 3-4-1-3-06 on the interpretation of Article 111 of the Estonian Constitution $<$ http://www.nc.ee>

146 De Witte (n 10) 69-71, with respect to the founding Member States.

147 I Pernice, 'Multilevel Constitutionalism and the Treaty of Amsterdam: European Constitution-making Revisited’ 36 CMLRev (1999) 713, 716.
} 
First, as was the practice in the old Member States of France and Spain, the constitution needed to be modified prior to accepting a new European obligation, such as certain provisions of the Maastricht Treaty, which would run counter to the constitution. Strikingly, the overwhelming majority of new Member States also stick to the unfettered primacy of their constitution over European law, possibly for two main reasons. In political terms, against the backdrop of the former Soviet domination, the Baltic and Central and Eastern European constitutions protect sovereignty to a much higher degree than Western European constitutions. ${ }^{148}$ Moreover, as a matter of legal tradition, the Kelsenian concept of a pyramid norm hierarchy had previously been lost under Communist rule and now holds the charm of being recently rediscovered; ${ }^{149}$ and this concept naturally places the State constitution on the top of the domestic pyramid. ${ }^{150}$

Second, the opposite approach has been adopted by Ireland, where the Constitution itself contains a rule that Community law is applicable in the domestic system according to its own principles, including the rule of supremacy. Among the new Member States, this model seems to have inspired only Cyprus so far; the Estonian Act Supplementing the Constitution has been interpreted by the Estonian Supreme Court to grant unconditional supremacy to Community law as well. ${ }^{151}$ Certain formulations in the Slovenian integration clause may be open for similar interpretation. As in Austria, the very special ratification procedures may serve as an additional argument to accord constitutional value to Community law in those constitutions.

Third, a middle way is to generally accept the supremacy of Community law over constitutional law by virtue of the integration clause, but to safeguard certain fundamental constitutional principles against the supremacy of Community law over domestic law with reference to

148 A Albi, "Europe” - Articles in the Constitutions of Central and Eastern European Countries' 42 CMLRev (2005) 399, 403.

149 Z. Kühn, 'The Application of European Law in the New Member States: Several (Early) Predictions' 6 German Law Journal (2005) 563, 574.

150 This contribution does not discuss whether the Kelsenian concept is the correct theoretical approach to define the relationship between European law and domestic law. For interesting theoretical propositions, see eg M Kumm, 'The Jurisprudence of Constitutional Conflict: Constitutional Supremacy in Europe before and after the Constitutional Treaty' 11 European Law Journal (2005) 262. For views in favour of an approach based on the pluralism of coordinated legal orders rather than on a norm hierarchy in the Kelsenian sense, see I Pernice, 'Das Verhältnis europäischer zu nationalen Gerichten im Europäischen Verfassungsverbund' <http://www.whi-berlin.de> 1-55, 44ff with further references.

151 A Albi 'Supremacy of EC Law in the New Member States - Bringing Parliaments into the Equation of "Co-operative constitutionalism" 3 EuConst (2007) 45. 
the limits contained in the very same clauses. ${ }^{152}$ Such reserve powers could be exercised, for example, in Italy, Germany or Denmark. Inspired by these precedents, the Constitutional Court of the Czech Republic followed that direction as well.

\section{Specific constitutional clauses relating to EU matters}

The horizontal integration clauses discussed so far are by definition abstract norms. Where they provide for the supremacy of European law over constitutional law, there is no need to address specific subject matters of possible conflict. However, where they preserve the possibility that constitutional law takes precedence over European law, it is necessary to introduce specific clauses relating to certain EU matters. Such specific constitutional clauses would then bring the national constitution in conformity with a particular piece of the acquis. For example, in France, any incompatibilities between a new EU treaty and the French Constitution regularly led to constitutional amendments to pave the way for ratification. Likewise, the Polish Constitutional Court has explicitly reminded the national Parliament that any possible conflict between European law and Polish constitutional law could be solved by changing the Polish Constitution. Hence, it is useful to briefly summarise the policy areas where specific constitutional clauses have been used in the past. ${ }^{153}$

\section{Voting rights}

Under Article 19 (1) EC, every citizen of the Union residing in a Member State of which he is not a national shall have the right to vote and to stand as a candidate at municipal elections in the Member State where he resides, under the same conditions as nationals of that State. From the domestic perspective, there is an EU obligation to grant the right to vote in municipal elections to $\mathrm{EU}$ foreigners.

However, under many constitutions the right to vote is reserved for nationals only, irrespective of whether the elections take place at national or local level. On the other hand, granting a constitutional right to nationals may not necessarily imply that no right can be granted to non-nationals by virtue of EU law. That was, for example, the view of the Polish Constitutional Court with respect to Article 62 (1) of the Polish constitu-

152 De Witte (n 10) 76 has called this the 'double capacity' of the integration clauses, namely to allow on the one hand for the smooth integration of EC law into the national legal system, and on the other hand to allow the constitutional courts to protect what they consider to be the core of the constitution against EU encroachments.

153 See also Albi (n 9) 42 CMLRev (2005) 419 and 401. 
tion. ${ }^{154}$ Similarly, the Estonian Chancellor of Justice argued before the Supreme Court that Article 48 (1) of the Estonian Constitution on the right of Estonian nationals to become members of political parties should be interpreted in the light of Article $19 \mathrm{EC}$ by virtue of Article 2 of the Act Supplementing the Constitution so as to grant EU citizens that right as well. ${ }^{155}$ Nevertheless, in order to remove any interpretative uncertainties, several other EU Member States have opted to tackle the issue directly by modifying their respective constitutional provision on the right to vote. This was the case in Germany, ${ }^{156}$ Austria, ${ }^{157}$ Belgium, ${ }^{158}$ France, ${ }^{159}$ Portugal, ${ }^{160}$ Spain, ${ }^{161}$ Hungary, ${ }^{162}$ Slovakia, ${ }^{163}$ Bulgaria, ${ }^{164}$ and Romania. ${ }^{165}$

\section{Extradition of nationals}

Under Framework Decision 2002/584/JHA of 13 June 2002, ${ }^{166}$ whose validity has recently been confirmed by the European Court of Justice, ${ }^{167}$ Member States are obliged to surrender persons to another Member State if the latter issues a European Arrest Warrant. The Framework Decision does not allow for the protection of one's own nationals. However, certain continental constitutional traditions incorporate a duty of the State to protect its own citizens from foreign criminal justice. Hence, a conflict between the constitution norm prohibiting extradition and the European Arrest Warrant may arise.

\footnotetext{
154 Constitutional Tribunal, Judgment of 11 May 2005, K 18/04, English translation available at <http://www.trybunal.gov.pl/eng/summaries/wstep_gb.htm> para 27.

155 A Albi, 'Estonia' in Kellermann, Czuczai and others (eds), Impact of EU Accession (n 8) 331, 337. The General Chamber of the Supreme Court decided on 19 April 2005 not to review Article 5 (1) of the Political Parties Act against norms of EU law, finding that it has no competence for such a review. Decision No 3-4-1-1-05, available in English at <http:// www.nc.ee>

156 Article 28 (1) third sentence of the Grundgesetz.

157 Article 23a and 117 (2) of the Austrian Constitution.

158 Article 8 (3) of the Belgium Constitution.

159 Article 88-3 of the French Constitution.

160 Article 15 (4) of the Portuguese Constitution.

161 Article 13 (2) of the Spanish Constitution.

162 Article 70 \& 2 of the Hungarian Constitution.

163 Article 30 (1) of the Slovak Constitution.

164 Article 42 (3) of the Bulgarian Constitution.

165 Article 16 (4) of the Romanian Constitution.

166 OJ 2002, L 190, 1.

167 ECJ, Case C-303/05, Judgment of the Grand Chamber of 3 May 2007, not yet reported, but available at <http://curia.europa.eu>
} 
In order to prevent such conflicts, Slovenia, ${ }^{168}$ Bulgaria, ${ }^{169}$ and Romania $^{170}$ modified the relevant constitutional provision prior to EU accession. In others, where such laudable caution was not applied, the conflict arose after accession. For example, as previously mentioned, the Supreme Court of Cyprus confirmed in November 2005 that Cyprus was unable to render citizens to other EU Member States, even though this entails a breach of the Framework Decision. In reply to this judgment, Cyprus modified its constitution. Next to the general EU clause already discussed, it modified Article 11 (2) (f) of the Constitution dealing specifically with deportation and extradition. Subparagraph (i) now incorporates the exception that Cypriot citizens may be handed over to other EU Member States on the basis of a European Arrest Warrant. Similarly, upon a finding of the Polish Constitutional Court that the surrender of Polish citizen to a Member State would run counter to Article 55 of the Polish Constitution, ${ }^{171}$ the latter was subsequently amended. Another solution was found by the Czech Constitutional Court: it declared that Article 14 (4) of the Czech Charter on Fundamental Rights, according to which no one can be forced to leave his home country, has to be construed narrowly and in accordance with EU law. That prohibition, according to the Court, was a reaction to the Communist crime to silence certain critics by forcing them to go abroad, but was not concerned with ordinary extradition cases.

\section{Acquisition of immovable property by foreigners}

The free movement of capital implies the right to purchase immovable property in other EU Member States, subject only to restrictions that are necessary to protect public policy or public security (Articles 56 and 58 (1) (b) EC). Community law therefore allows certain non-discriminatory administrative practices regulating the purchase of immovable property. However, an outright prohibition for foreigners to buy land is not compatible with the internal market. This is why a number of new Member States have sought transitional periods in this area, hitherto incorporated in the Treaty of Accession.

Nevertheless, once these transitional arrangements expire, constitutional protection can no longer be invoked. Against that background, certain new Member States modified the respective constitutional provision to allow for the purchase of land by EU citizens. Examples of such

\footnotetext{
168 Article 47 of the Slovene Constitution.

169 Article 25 (3) of the Bulgarian Constitution.

170 Article 19 (1) of the Romanian Constitution.

171 Polish Constitutional Tribunal, Judgment of 27 April 2005, Case P 1/05, English translation available at <http://www.trybunal.gov.pl/eng/summaries/wstep_gb.htm>
} 
modifications can be found in Slovenia, ${ }^{172}$ Lithuania, ${ }^{173}$ Romania, ${ }^{174}$ and in Bulgaria. ${ }^{175}$

\section{Economic and monetary union}

Under the EC Treaty, responsibility for the common monetary policy is vested in the European Central Bank. This implies that no national authority exercises this function anymore in those Member States which form part of the Eurozone. Sometimes this consequence is specifically taken into account in national constitutions. Examples of this technique can be found in Germany, ${ }^{176}$ France, ${ }^{177}$ Portugal, ${ }^{178}$ and Greece. ${ }^{179}$

Furthermore, under Article 109 EC, national central banks are independent. This may have an impact on constitutional provisions dealing with the status of the Central Bank. If a domestic provision can be interpreted as allowing for other state bodies to exert political influence on the bank, a conflict with European law is likely to occur. However, in discerning whether a conflict actually arises, not only the text of a provision implementing legislation and case law, ${ }^{180}$ but also constitutional practice is of importance. For example, Article 152 of the Slovene Constitution provides for the accountability of the bank to Parliament; under Article 91 of the Finnish Constitution, Parliament supervises the central bank and has the right to be informed. Nevertheless, as constitutional practice in these countries shows, these provisions have not put into jeopardy the independence of the respective banks. Nevertheless, there may be a case to modify the relevant constitutional provisions in order to provide for the incontrovertible independence of the national bank if serious practical doubts remain on the proper understanding of an ambivalent constitutional norm.

172 Article 68 of the Slovene Constitution.

173 Article 47 of the Lithuanian Constitution.

174 Article 41 (2) of the Romanian Constitution.

175 Article 22 of the Bulgarian Constitution.

176 Article 88, second sentence of the Grundgesetz.

177 Article 88-2, first subparagraph of the French Constitution.

178 Article 102 of the Portuguese Constitution.

179 Article 80 (2) of the Greek Constitution.

180 Note, for example, that the Czech Constitutional Court nullified certain provisions of the Amendment Act on the Czech National Bank (CNB) by reasoning that they were inconsistent not only with the requirement of the independent status of the CNB as guaranteed by the Czech Constitution, but also with Article 108 EC. Case Pl. Us 59/2000, Collection of Constitutional Court Decisions, Vol 22, 249. 


\section{Independence of the judiciary}

According to Article 6 (1) EU, the European Union is founded on the principles of liberty, democracy, respect for human rights and fundamental freedoms, and the rule of law, principles which are common to the Member States. As Article 49 EU directly refers to these principles as a criterion for accession, the European Union assesses whether a candidate country conforms to these principles prior to becoming a Member. ${ }^{181}$ Consequently, there is a growing body of "constitutional acquis" which candidate countries need to take into account. ${ }^{182}$

On this basis, the independence of the judiciary occasionally caused concern for European institutions in the last round of accession. ${ }^{183}$ Certainly, there is no single European model how to organise the judiciary in an EU country. Nevertheless, the rule of law requirement embodies the principle of separation of powers. In turn, this necessitates a judiciary independent of other branches of government. As laid down in the jurisprudence of the Strasbourg organs with respect to Article 6 (1) of the European Convention on Human Rights, Courts must be established by law; ${ }^{184}$ there shall be no discrimination in the appointment procedures of judges; ${ }^{185}$ the judiciary must not be influenced in its decision-making by either the executive or the legislature; ${ }^{186}$ judges must act impartially and be seen to do so; their conditions of tenure must be adequately ensured by law; ${ }^{187}$ the grounds for disciplinary action or removal from the post must be limited and laid down in the law.

181 For an interpretation of the constitutional dimension of the political accession criteria, see F Hoffmeister, 'Changing Requirements for Membership' in A Ott, K Kinglis (eds), Handbook on European Enlargement (Asser Press, 2002) 90, 93-96.

182 For a definition of the notion 'constitutional acquis', see J Czuczai, 'Practical Implementation by the Acceding Countries of the Constitutional Acquis of the EU - Problems and Challenges' in Kellermann, De Zwaan and Czuczai, EU Enlargement (n 8) 411, 421.

183 In "Europe" - Articles in the Constitutions of Central and Eastern European Constitutions' 42 CMLRev (2005) 415. Albi notes that it was a novelty of the last round of accession that the European Commission requested that provisions concerning the judiciary be amended. In fact, those requests were supported by the Council, as the latter adopted the Accession Partnerships and formulated negotiation positions on the basis of the Commission's Regular Reports and Draft Common Positions.

184 EComHR, Zand v. Austria, App No 7360/76, 15 DR 70 (1978).

185 ECtHR, Sramek $v$. Austria, Ser A 84, §§ 41-42.

186 ECtHR, Ringeisen v. Austria, Ser A 13, § 95; ECtHR, Piersack v. Belgium, Ser A 53, § 27; ECtHR, Beaumartin v. France, Ser A 296-B, § 38; ECtHR, Van de Hurk v. the Netherlands, Ser A 288, §§ 50-52.

187 ECtHR, Campbell and Fell vs. UK, Ser A 80, § 80: 'It is true that the irremovability of judges by the executive during their term of office must in general be considered as a corollary of their independence and thus included in the guarantees of Article 6 (1). However, the absence of a formal recognition of this irremovability in the law does not in itself imply lack of independence provided that it is recognised in fact and that the other necessary guarantees are present.' 
Against this background, the Accession Partnership for Slovakia of December 1999 had laid down the short term priority to 'strengthen the independence of the judiciary, in particular amend the constitution with regard to nomination and probationary system for judges. ${ }^{188}$ This partially explains the considerable number of amendments concerning the position of the judiciary in the 2001 constitutional reform of Slovakia. ${ }^{189}$ Similarly, a significant number of amendments of the 2003 constitutional package in Romania related to the judiciary, ${ }^{190}$ following relevant remarks in the European Commission Regular Reports on this country. ${ }^{191}$ The same can be said for Bulgaria, where a separate constitutional package of September 2003 was passed in order to comply with concerns from Brussels. The reform limited the immunity for top-level magistrates, clarified the conditions of removal and fixed their terms of office. ${ }^{192}$ Currently, many of these discussions are being conducted with Croatia and Turkey in a newly formed negotiation Chapter 23 called judiciary and human rights'.

\section{Conclusion}

EU membership has a number of constitutional implications for the Member States. In order to apply European law domestically, many Member States provide for a constitutional basis that defines the domestic applicability and rank of European law. To meet this challenge, there is a clear trend not to use existing constitutional clauses relating to international treaties, international organisations or association of States. Rather, new integration clauses are specifically designed for EU membership. Such EU integration clauses trigger specific ratification procedures that go beyond ordinary parliamentary majorities, in many cases involving referenda. Since accession to the EU is then endowed with a particularly high degree of legitimacy, Member States also accept that Community law supersedes national law. Nevertheless, some constitutional reserves occasionally remain, in particular when the highest Courts of a country have a textual basis for arguing that certain constitutional essentials are not even open to change for the constitutional legislator. In such a scenario, the very same constitutional essentials are also safeguarded against a (theoretically) deficient piece of Community law.

188 The Accession Partnership of December 1999 is cited in the Commission's Regular Report on Slovakia's Progress Towards Accession, 8 November 2000, 16.

189 Albi, EU Enlargement and the Constitutions of Central and Eastern Europe (n 9) 69.

190 For more details, compare V Duculescu, R Adam, 'Romania' in Kellermann, Czuczai and others (eds), Impact of EU accession (n 8) 113, 116 and 124-128.

191 Albi, EU Enlargement and the Constitutions of Central and Eastern Europe (n 9) 106.

192 For more details, compare E Tanchev, J Peteva, 'Bulgaria' in Kellermann, Czuczai and others (eds), Impact of EU Accession (n 8) 33, 45-46. 
In order to overcome conflicts between certain circumscribed matters of Community law and domestic constitutional law, many Member States have, in addition, introduced specific constitutional provisions that are limited to regulate these conflicts. It is wise to address these particular policy fields in advance of EU membership to avoid the embarrassing situation where national courts must apply the domestic constitution instead of Community law. Rather than being forced to modify the constitution ex post under time pressure, preventive action seems to be more appropriate.

The European Commission does not prescribe a specific method on how a candidate should address these issues. Rather, during the negotiations, it points to certain shortcomings as they arise in the negotiation chapters. There is an obligation of result to provide for the supremacy of Community law by accession. The choice on how and when to opt for a constitutional model which is best reconcilable with the candidate's own national tradition certainly remains in the hands of the democratically elected representatives of the candidate country itself. ${ }^{193}$

193 The same conclusion was reached vis-à-vis the previous enlargement by J Czuczai (n 182) 411,422 . 